Nhiều nghiên cứu khác cho kết quả khác nhau về mối liên hệ giữa độ dày thủy tinh thể và giới tính có kết quả trái ngược nhau, và thậm chí trong nghiên cứu của He và cộng sự, giá trị này được báo cáo lớn hơn ở phụ nữ[1],[5].

\section{KẾT LUẬN}

Trong nghiên cứu của chúng tôi, lần đầu tiên chỉ số nhân trắc vềchiều dài trục nhãn câuu, độ sâu tiền phòng, độ dày giác mạc trung tâm và độ dày thủy tinh thểđược xác định ở người Việt Nam 46-65 tuổi. So với kết quả của các nghiên cứu được tiến hành trên thế giới chỉ số này ở người Việt Nam 46-65 tuổi tương đồng với kết quả nghiển cứu ở trên người châu Á và nhỏ hơn các chỉ số được nghiên cứu trên người châu Âu và Mỹ. Chiều dài trục nhãn câu, độ sâu tiền phòng, độ dày giác mạc trung tâm giảm theo tuổi và cao hơn ở nam giới so với nữ giới.Độ dày thủy tinh thể tăng dần theo tuổi và không có sự khác biệt giữa nam giới và nữ giới.

\section{TÀI LIẸU THAM KHẢO}

1. Mingguang He, Wenyong Huang, Yuetao Li và công sứ (2009). Refractive error and biometry in older Chinese adults: the Liwan eye study. Investigative ophthalmology \& visual science, 50 (11), 5130-5136
2. Chrisandra Shufelt, Samantha Fraser-Bell, Mei Ying-Lai và công sứ (2005). Refractive error, ocular biometry, and lens opalescence in an adult population: the Los Angeles Latino Eye Study. Investigative ophthalmology \& visual science, 46 (12), 4450-4460.

3. Maria Teresa Zocher, Jos J Rozema, Nicole Oertel và cộng sự (2016). Biometry and visual function of a healthy cohort in Leipzig, Germany. BMC ophthalmology, 16 (1), 79.

4. Nicola S Logan, Leon N Davies, Edward AH Mallen và cộng sứ (2005). Ametropia and ocular biometry in a UK university student population. Optometry \& Vision Science, 82 (4), 261-266.

5. Hassan Hashemi, Mehdi Khabazkhoob, Mohammad Miraftab và cộng sự (2012). The distribution of axial length, anterior chamber depth, lens thickness, and vitreous chamber depth in an adult population of Shahroud, Iran. BMC ophthalmology, 12 (1), 50.

6. Hassan Hashemi, Soheila Asgari, Shiva Mehravaran và cộng sự (2011). The distribution of corneal thickness in a 40-to 64-year-old population of Shahroud, Iran. Cornea, 30 (12), 1409-1413.

7. MR Praveen, AR Vasavada, SK Shah và cộng sự (2009). Lens thickness of Indian eyes: impact of isolated lens opacity, age, axial length, and influence on anterior chamber depth. Eye, 23 (7), 1542.

8. Sora Hahn, Stanley Azen, Mei Ying-Lai và cộng sự (2003). Central corneal thickness in Latinos. Investigative ophthalmology \& visual science, 44 (4), 1508-1512.

\title{
KHẢO SÁT NỒNG Đô PROTEIN PHẢN ỨNG C Ở BỆNH NHÂN ĐÁI THÁO ĐƯờNG TÍP 2 Có BỆNH THẬN MẠN
}

Bùi Hữu Hoàng1, Đào Bùi Quý Quyền ${ }^{2}$, Lê Việt Thắng ${ }^{3}$

\section{TÓM TẮT}

Mục tiêu: Xác định nồng độ hs-CRP huyết tương ở bệnh nhân đái tháo đường típ 2 có bệnh thận mạn. Đối tượng và phương pháp: Nghiên cứu cắt ngang trên 156 đối tượng bao gồm 98 bệnh nhân ĐTĐ típ 2 có BTMT và 58 bệnh nhân không có BTMT. Tất cả các bệnh nhân được định lượng nồng độ hs-CRP huyết tương theo phương pháp đo độ đục phản ứng miền dịch. Kết quả: Nồng độ hs-CRP huyết tương trung bình ở nhóm ĐTĐ có BTMT là 2,34 $(1,31-3,96) \mathrm{mg} / \mathrm{L}$, cao hơn nhóm không có BTMT là $1,7 \quad(0,78-3,08)$ $\mathrm{mg} / \mathrm{L}, \mathrm{p}<0,05$. Tỷ lê bênh nhân ĐTĐ có BTMT tăng hs-CRP là $17,3 \%$ cao hơn nhóm không có BTMT là $1,7 \%, p<0,05$. Nhóm bệnh nhân ĐTÐ có BTMT kèm

${ }^{1}$ Bênh viên Nhân dân 115

${ }^{2}$ Bềnh viện Chợ Rẫy, TPHCM

${ }^{3}$ Họ viến Quấn y

Chịu trách nhiệm chính: Lê Việt Thắng

Email: lethangviet@yahoo.com.uk

Ngày nhận bài: 4/4/2021

Ngày phản biên khoa hoc: 8/5/2021

Ngày duyệt bài: 20/5/2021
RLLP máu; kiểm soát glucose máu kém; có biến chứng khác ngoài thận có nồng độ hs-CRP cao hơn nhóm không có đặc điểm trên, $p<0,05$. Kết luận:Tổn thương thận ở người bệnh ĐTĐ típ 2 làm tăng nồng độ hs-CRP huyết tương.

Tư khóa: Đái tháo đường típ 2, Bệnh thận mạn tính, Protein phản ứng $\mathrm{C}$ độ nhạy cao.

\section{SUMMARY \\ SURVEY ON CONCENTRATION OF PLASMA \\ HS-CRP IN TYPE 2 DIABETIC MELLITUS PATIENTS WITH CHRONIC NEPHROPATHY}

Objectives: To determine of plasma hs-CRP levels in type 2 diabetic mellitus (DM) with chronic nephropathy $(\mathrm{CN})$. Subjects and Methods: Crosssectional study on 156 subjects including 98 patients diagnosed type 2 DM with $\mathrm{CN}$ and 58 patients without CN. Plasma hs-CRP levels were quantified by immunoassay turbidity in al the patients. Results: The median plasma hs-CRP concentration in the DM group with CN was $2.34(1.31-3.96) \mathrm{mg} / \mathrm{L}$, higher than the group without $\mathrm{CN}$ was $1.7(0.78-3.08) \mathrm{mg} / \mathrm{L}$, $\mathrm{p}<0.05$. The proportion of serum hs-CRP increase inDM patients with $\mathrm{CN}$ was $17.3 \%$ higher than that of 
the DM group without $\mathrm{CN}$ of $1.7 \%, \mathrm{p}<0.05$. The hsCRP concentration in group of DM patients with $\mathrm{CN}$ and lipid disorders; poor blood glucose control; with complications others, was higher than of the one without the above characteristics, $p<0.05$. Conclusion: Kidney damage in type 2 DM patients increases the plasma hs-CRP concentration.

Keywords: Type 2 diabetic mellitus, Chronic Nephropathy, hs-CRP.

\section{I. ĐĂT VẤN ĐỀ}

Protein phản ứng $C$ là một marker viêm liên quan đến quá trình xơ vữa mạch máu, quá trình viêm ở nhiêu bệnh lý mạn tính trong đó có đái tháo đường típ 2. Nhiều nghiên cứu cho thây nồng độ protein phản ứng $C$ tăng ở bệnh nhân đái tháo đường khi chưa có biến chứng man tính. Ở bệnh nhân đái tháo đường có bệnh thận mạn tính, protein phản ứng $C$ tăng với tỷ lệ cao hởn, mức độ nặng hơn. Protein phản ứng $C$ còn được xem như yếu tố tiên lượng tổn thương thận ở bệnh nhân đái tháo đường típ 2 và tiên lượng tử vong ở bệnh nhân đái tháo đường có bệnh thận mạn tính [1],[2]. Protein phản ứng $C$ có độ nhạy cao (hs-CRP) còn được xem như yếu tố nguy cơ tim mạch ở bệnh nhân ĐTĐ có và chưa có bệnh thận mạn [2]. Xuất phát từ những lý do trên, chúng tôi thực hiện đề tài này với mục tiêu: Khảo sát nồng độ hs-CRP huyêt tương ở bệnh nhân đái tháo đường típ 2 có bệnh thận mạn tính.

\section{II. ĐỐI TƯỢNG VÀ PHƯƠ'NG PHÁP NGHIÊN CỨU}

1. Đối tượng nghiên cứu. Đối tượng là 156 người bệnh được chia làm 2 nhóm:

- Nhóm nghiên cứu (Nhóm 1): Là 98 người bệnh ĐTĐ típ 2 có BTMT.

- Nhóm chứng bệnh (Nhóm 2): Là 58 người bệnh ĐTÐ típ 2 không có BTMT.

- Thời gian nghiên cứu từ tháng 4/2020 đến tháng 4/2021.

- Nơi nghiên cứu: Bệnh viện nhân dân 115.

Tiêu chuẩn chọn bệnh nhân:

- Bệnh nhân được chẩn đoán ĐTĐ típ 2 đang được theo dõi và điều trị tại Bệnh viện.

- Gồm 2 nhóm có và không có BTMT (BTMT được xác định sau ĐTĐ típ 2).

- Bệnh nhân đồng ý tham gia nghiên cứu

Tiêu chuẩn loại bệnh nhân:

- Bệnh nhân tại thời điểm nghiên cứu nghi ngờ mắc bệnh ngoại khoa.

- Bệnh nhân viêm nhiễm nặng như viêm phổi, viêm tuy cấp...

- Các bệnh nhân không đủ tiêu chuẩn nghiên cứu.

\section{Phương pháp nghiên cứu}

- Nghiên cứu mô tả, cắt ngang so sánh bệnh và chứng bệnh.

- Tính cỡ mẫu theo công thức: Chọn mẫu thuận tiện trong thời gian nghiên cứu.

- Bênh nhân được hỏi bênh sử, khám lâm sàng. Các xét nghiệm cận lẩm sàng bao gồm: xét nghiệm công thức máu, sinh hoá máu các chì số: glucose, ure, creatinine, albumin, protein..., nước tiểu 10 chỉ tiêu, siêu âm thận, protein niệu 24 giờ nếu cần. Tính mức lọc cầu thận theo công thức MDRD.

- Bênh nhân có MLCT < $60 \mathrm{ml} /$ phút và hoăc protein niệu $(+)$ trong 3 tháng liên tục được xểp nhóm 1 , những bệnh nhân có MLCT $\geq 60$ $\mathrm{ml} /$ phút và protein niệu (-) được xếp nhóm 2.

- Định lượng hs-CRP huyết tương theo nguyên lý đo độ đục phản ứng miễn dịch kháng nguyên kháng thể tăng cường trên hạt Latex. Chẩn đoán tăng hs-CRP khi $>5 \mathrm{mg} / \mathrm{L}$.

- Phân tầng nguy cơ tim mạch theo nồng độ hs-CRP: < $1 \mathrm{mg} / \mathrm{L}$ : mức độ nhẹ, 1-3 mg/L: mức độ vừa và $>3 \mathrm{mg} / \mathrm{L}$ : mức cao [3].

3. Xử lý số liệu: Số liệu được xử lý bằng thuật toán thống kê y sinh học theo chương trình SPSS 20.0

\section{KẾT QUẢ NGHIÊN CỨU}

Tuổi trung bình nhóm bênh nhân ĐTÐ típ 2 có BTMT là $69,87 \pm 14,18$, tỷ lệ nam là $41,8 \%$, nữ chiếm $58,2 \%$. Mức lọc cầu thận trung bình là $52,46(44,66$ - 58,96) ml/phút, trong đó có 77,5\% bệnh nhân có BTMT giai đoạn 3 đến 5 .

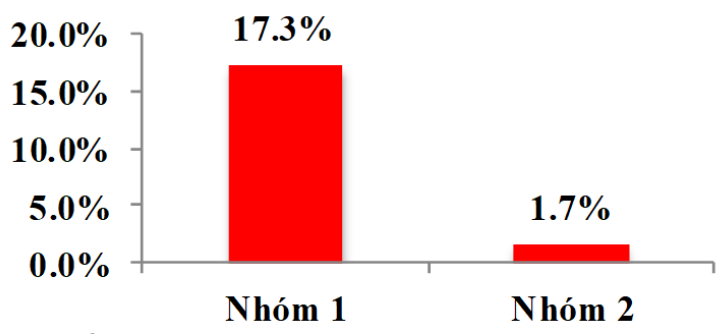

Biểu đồ 1. So sánh tỷ lệ tăng hs-CRP nhóm ĐTÐ típ 2 có BTMT và không có BTMT

Nhận xét: Nhóm bệnh nhân ĐTÐ típ 2 có BTMT có tỷ lệ tăng hs-CRP cao hơn nhóm bệnh nhân ĐTĐ típ 2 không có BTMT, $\mathrm{p}<0,001$.

Bảng 1. Liên quan nồng độ hs-CRP huyêt tương với tuôi và giới $(n=98)$

\begin{tabular}{|c|c|c|c|}
\hline \multicolumn{2}{|r|}{ Đặc điểm } & $\begin{array}{l}\text { Số bệ̂nh } \\
\text { nhẩn }\end{array}$ & $\begin{array}{l}\text { Tỷ lệ } \\
(\%)\end{array}$ \\
\hline Nữ & Tăng & 10 & 17,5 \\
\hline$(n=57)$ & Trung vị (Tứ phân vị) & $2,7(1,44$ & $-4,3)$ \\
\hline Nam & Tăng & 7 & 17,1 \\
\hline$(n=41)$ & Trung vị (Tứ phân vị) & $1,86(1,18$ & $-3,28)$ \\
\hline
\end{tabular}


VIETNAM MEDICAL JOURNAL N² - JUNE - 2021

\begin{tabular}{|c|c|c|c|}
\hline \multirow{2}{*}{$\begin{array}{c}\geq 60 \\
\text { tuổi } \\
(n=77)\end{array}$} & Tăng & 12 & 15,6 \\
\hline & $\begin{array}{c}\text { Trung vị } \\
\text { (Tứ phân vị) }\end{array}$ & \multicolumn{2}{|c|}{$2,52(1,37-3,92)$} \\
\hline \multirow{2}{*}{$\begin{array}{l}<60 \text { tuối } \\
(n=21)\end{array}$} & Tăng & 5 & 23,5 \\
\hline & Trung vị & \multicolumn{2}{|c|}{2,05} \\
\hline
\end{tabular}

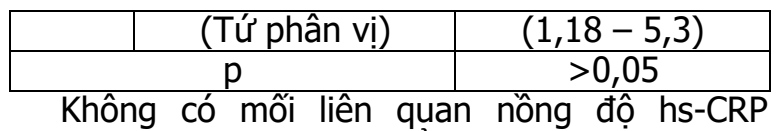
huyết tương với giới và tuổi cao, p> 0,05.

Bảng 1. So sánh tỷ lệ bệnh nhân theo phân tầng nguy cơ tỉm mạch của nồng độ hsCRP ở 2 nhóm

\begin{tabular}{|c|c|c|c|c|}
\hline Mức nồng độ hs-CRP & Chung (n=156) & Nhóm 1 (n=98) & Nhóm 2 (n=58) & P \\
\hline Nguy cơ thấp $<1,0 \mathrm{mg} / \mathrm{L}(\mathrm{n}, \%)$ & $28(17,9)$ & $11(11,2)$ & $17(29,3)$ & \\
\cline { 1 - 4 } Nguy cơ trung bình: & $75(48,1)$ & $49(50)$ & $26(44,8)$ & $<0,05$ \\
1,0 đến $3,0 \mathrm{mg} / \mathrm{L}$ & $53(34)$ & $38(38,8)$ & $15(25,9)$ & \\
\hline Nguy cơ cao: $>3,0 \mathrm{mg} / \mathrm{L}$ & $2,1(1,19-3,55)$ & $2,34(1,31-3,96)$ & $1,7(0,78-3,08)$ & $<0,05$ \\
\hline Trung vị (Tứ phân vị), $\mathrm{mg} / \mathrm{L}$ & &
\end{tabular}

Nhóm bệnh nhân ĐTĐ có BTMT có nồng độ trung bình hs-CRP huyết tương cao hơn, tỷ lệ bệnh nhân ở mức nguy cơ cao cũng cao nhóm nhóm chứng bệnh, $\mathrm{p}<0,05$.

Bảng 3. Liên quan với rối loạn lipid máu và tình trạng kiểm soát glucose máu

\begin{tabular}{|c|c|c|c|}
\hline \multicolumn{2}{|c|}{ Đặc điểm } & $\begin{array}{l}\text { Số bệnh } \\
\text { nhẩn }\end{array}$ & $\begin{array}{l}\text { Tỷ lệ } \\
(\%)\end{array}$ \\
\hline \multirow{2}{*}{$\begin{array}{l}\text { Có RLLP máu } \\
(n=57)\end{array}$} & Tăng & 15 & 22,4 \\
\hline & $\begin{array}{c}\text { Trung vị } \\
\text { (Tứ phân vị) }\end{array}$ & \multicolumn{2}{|c|}{$2,88(1,36-4,73)$} \\
\hline \multirow{2}{*}{$\begin{array}{l}\text { Không } \\
(n=41)\end{array}$} & Tăng & 2 & 6,5 \\
\hline & $\begin{array}{l}\text { Trung vị } \\
\text { (Tứ phân vi) }\end{array}$ & \multicolumn{2}{|c|}{$1,58(1,12-2,61)$} \\
\hline \multicolumn{2}{|c|}{$\mathrm{OR}, \mathrm{p}$} & \multicolumn{2}{|c|}{$\mathrm{OR}=4,183, \mathrm{p}<0,005$} \\
\hline \multirow{2}{*}{$\begin{array}{l}\text { Kiểm soát } \\
\text { kém }(n=70)\end{array}$} & Tăng & 14 & 20,0 \\
\hline & $\begin{array}{c}\text { Trung vị } \\
\text { (Tứ phân vị) }\end{array}$ & \multicolumn{2}{|c|}{$2,54(1,51-4,55)$} \\
\hline \multirow{2}{*}{$\begin{array}{l}\text { Tốt+Chấp } \\
\text { nhận được } \\
(\mathrm{n}=28)\end{array}$} & Tăng & 3 & 10,7 \\
\hline & $\begin{array}{l}\text { Trung vị } \\
\text { (Tứ phân vị) }\end{array}$ & \multicolumn{2}{|c|}{$1,54(1,09-3,26)$} \\
\hline \multicolumn{2}{|c|}{$\mathrm{OR}, \mathrm{p}$} & \multicolumn{2}{|c|}{$\begin{array}{l}\text { OR=2,083, } p>0,05 ; \\
p \text { trung bình }<0,05\end{array}$} \\
\hline
\end{tabular}

\begin{tabular}{|c|c|c|}
\hline & (Tứ phân vị) & $(1,28-4,43)$ \\
\hline \multirow{2}{*}{$\begin{array}{c}\text { Giai đoạn } 1 \\
2(n=23)\end{array}$} & Tăng & 13,0 \\
\hline & $\begin{array}{c}\text { Trung vị } \\
\text { (Tứ phân vi) }\end{array}$ & $\begin{array}{c}2,6 \\
(1,36-3,5)\end{array}$ \\
\hline \multicolumn{2}{|c|}{$\mathrm{OR}, \mathrm{p}$} & $\mathrm{OR}=1,53, p>0,05$ \\
\hline \multirow{2}{*}{$\begin{array}{l}\text { Có biến } \\
\text { chứng khác } \\
(\mathrm{n}=82)\end{array}$} & Tăng & 20,7 \\
\hline & $\begin{array}{l}\text { Trung vị } \\
\text { (Tứ phân vị) }\end{array}$ & $\begin{array}{c}2,58 \\
(1,4-4,59)\end{array}$ \\
\hline \multirow{2}{*}{$\begin{array}{c}\text { Không có } \\
(n=16)\end{array}$} & Tăng & 0,0 \\
\hline & $\begin{array}{l}\text { Trung vị } \\
\text { (Tứ phân vị) }\end{array}$ & $1,81(0,83-2,55)$ \\
\hline & p & $<0,05$ \\
\hline
\end{tabular}

Không có mối liên quan nồng độ hs-CRP với giai đoan bệnh thận man tính, tuy nhiênnhóm bệnh nhân có biến chứng ngoài thận có tỷ lệ tăng và nồng độ hs-CRP trung bình cao hơn nhóm không có biến chứng ngoài thận, $\mathrm{p}<0,05$.

\section{BÀN LUÂ̂N}

1. Đặc điểm nồng độ hs-CRP ở nhóm nghiên cứu: Tăng nồng độ hs-CRP là tương đối phổ biến ở bệnh nhân ĐTĐ típ 2. Nhiêuu bằng chứng cho thẩy rằng viêm có thể đóng một vai trò trung gian quan trọng trong cơ chế bệnh sinh của bệnh ĐTÐ típ 2. CRP là một protein huyết tương pha cấp tính được tổng hợp bởi gan và đãđược chứng minh là một dấu ẩn sinh học hê thống, nhạy cảm đối với tình trạng viêm.

glucose máu lúc đói kém có nồng độ hs-CRP cao hơn nhóm không có đặc điểm trên, p $<0,05$.

Bảng 4. Liên quan với giai đoạn bệnh thận và biến chứng ngoài thận

\begin{tabular}{|c|c|c|c|}
\hline \multicolumn{2}{|c|}{ Đặc điểm } & $\begin{array}{c}\text { Số bệ̂nh } \\
\text { nhẩn }\end{array}$ & $\begin{array}{c}\text { Tỷ lệ } \\
(\%)\end{array}$ \\
\hline Giai đoạn 3- & Tăng & 14 & 18,7 \\
\cline { 2 - 4 } (n=广்) & Trung vị & \multicolumn{2}{|c|}{2,18} \\
\hline
\end{tabular}

Bảng 1. So sánh đặc điểm hs-CRP với các nghiên cứu trong và ngoài nước

\begin{tabular}{|c|c|c|c|}
\hline Tác giả & Đối tượng & $\begin{array}{c}\text { Tỷ lệ tăng } \\
\text { (>5,0 } \mathrm{mg} / \mathrm{L})\end{array}$ & $\begin{array}{l}\text { Nồng độ trung bình } \\
\text { (Trung vị-mg/L) }\end{array}$ \\
\hline $\begin{array}{l}\text { Varma V. và } \\
\text { cộng sự năm } \\
2016 \text { [1] }\end{array}$ & $\begin{array}{l}\text { - } 157 \text { ĐTĐ típ } 2 \text { có BTMT, có nồng độ } \\
\text { creatinine trung bình là 1,46 mg/dl. } \\
\text { - } 162 \text { BN ĐTĐ típ } 2 \text { không BTMT }\end{array}$ & - & $\begin{array}{r}3,2 \\
2,07\end{array}$ \\
\hline $\begin{array}{l}\text { Sinha S.K. và } \\
\text { cộng sự năm } \\
2019 \text { [4] }\end{array}$ & $\begin{array}{c}\text { - } 323 \text { BN ĐTÐ típ } 2 \text { có BTMT có } \\
\text { MLCT trung bình } 88,27 \text { ml/phút. } \\
-3270 \text { ĐTÐ típ } 2 \text {. }\end{array}$ & - & $\begin{array}{l}3,36 \pm 3,3 \\
2,36 \pm 3,4\end{array}$ \\
\hline $\begin{array}{c}\text { Trân Minh Triết } \\
\text { năm } 2019 \text { [5] }\end{array}$ & $\begin{array}{l}\text { - } 275 \text { bệnh nhân tiền ĐTÐ } \\
\text { - } 116 \text { người bình thường }\end{array}$ & & $\begin{array}{l}2,81 \\
1,79 \\
\end{array}$ \\
\hline
\end{tabular}




\begin{tabular}{|c|c|c|c|}
\hline \multirow{2}{*}{ Chúng tôi 2021} & 156 bệnh nhân ĐTĐ típ 2: & $11,5 \%$ & 2,1 \\
& -98 có BTMT & $17,2 \%$ & 2,34 \\
& -58 không có BTMT & $1,7 \%$ & 1,7 \\
\hline
\end{tabular}

Khi bệnh nhân có tổn thương thận, nhiều yếu tố ở nhóm bệnh nhân này làm gia tăng nồng độ các dấu ấn viêm trong máu bệnh nhân. Phản ứng viêm không chỉ là một quá trình tại chỗ mà nó còn có thể được phản ánh một cách hệ thống, vì nó đi kèm với sự gia tăng các dấu hiệu viêm bao gồm protein giai đoạn cấp tính, cytokine và các phân tử kết dính. Trên thực tế, tình trạng viêm dai dẳng cũng có thể là một yếu tố nguy cơđối với sự tiến triển của BTMT trên bệnh nhân ĐTÐ típ 2 , vì các dấu hiệu viêm là những yếu tố dự báo suy giảm chức năng thận. Ngoài ra, CRP hình thành cục bộ trong quá trình tổn thương thận làm giảm sản xuất oxit nitric, kích thích sự hình thành endothelin-1 và gây ra một số bước liên quan đến quá trình xơ vữa động mạch. Do đó, tình trạng viêm có thể thúc đẩy cả tổn thương thận (gẩy rối loạn chức năng nội mô, xơ vữa động mạch và tổn thương cầu thận) và tử vong do tim mạch.Mặc dù các cơ chế chính xác góp phần vào tỷ lệ viềm nhiếm cao ở bệnh thận mạn chưa được thiết lập rõ ràng, các gốc tự do đã được đề xuất như là những yếu tố tiềm năng gây ra tình trạng viêm khi chức năng thận suy giảm. Phân tầng nguy cơ tim mạch dựa trển nhóm bệnh nhân nghiên cứu chúng tôi nhận thây nhóm Đ̇TĐ có tổn thương thận chủ yểu mức hs-CRP ở mức trung bình và cao chiếm $88,8 \%$, ngược lại nhóm ĐTÐ chưa tổn thương thận thì mức thấp và trung bình chiếm $74,1 \%$. Về phân tầng nguy cơ theo Trần Thị Thu Hương và cộng sự năm 2013 [6] cho thây trong 203 cán bộ diện bảo vệ sức khoẻ có $53,7 \%$ mức hs-CRP ở nguy cơ thấp, $39,4 \%$ trung bình và $6,9 \%$ nguy cơ cao. Như vậy, ngay cả khi người bình thường đã có nhiều yểu tố tiềm ẩn tăng nồng độ CRP máu. Với kết quả của chúng tôi, các nhà lâm sàng cần chú ý kiểm soát tốt hơn nữa các yếu tố nguy cơ của viêm ở người bệnh ĐTĐ típ 2 có và không có tổn thương thận để giảm nguy cơ tim mạch ở nhóm bệnh nhân này.

2. Liên quan nồng độ hs-CRP với một số yếu tố: Chúng tôi nhận thấy nhóm BN có RLLP máu có nồng độ hs-CRP trung bình cao hơn nhóm không RLLP máu, $p<0,005$. Jeong $H$ và cộng sự năm 2019 [7] đã nghiên cứu trên 5887 người tuổi từ 19 trở lên (tuổi trung bình 46,7 tuổi), thấy mối liên quan giữa CRP với RLLP máu, ĐTĐ và hội chứng chuyển hoá ở quần thể nghiên cứu. Chúng tôi nhận thấy rằng nhóm bệnh nhân kiểm soát glucose máu kém có nồng độ hs-CRP cao hơn nhóm kiểm soát được và tốt, $\mathrm{p}<0,05$. Biến chứng ngoài thận thường đi kèm với tình trạng kiểm soát glucose máu kém. Kết quả nghiên cứu của chúng tôi cho thấy, những bệnh nhân có thêm các biến chứng khác ngoài thận có nồng độ trung bình và tỷ lệ tăng nồng độ hs-CRP, cao hơn nhóm chỉ có biến chứng thận. Những kết quả này một lần nữa cho thây mối liên quan giữa viêm và mức độ tiến triển bệnh ở bệnh nhân ĐTĐ típ 2.

\section{KẾT LUÂ̂N}

- Nồng độ hs-CRP huyết tương trung bình ở nhóm ĐTÐ có BTMT là 2,34 $(1,31$ - 3,96) $\mathrm{mg} / \mathrm{L}$, cao hơn nhóm không có BTMT là 1,7 (0,78 $3,08) \mathrm{mg} / \mathrm{L}, \mathrm{p}<0,05$. Tỷ lệ bệnh nhân ĐTÐ có BTMT tăng hs-CRP là $17,3 \%$ cao hơn nhóm không có BTMT là $1,7 \%, p<0,05$.

- Nhóm bênh nhân ĐTĐ có BTMT có RLLP máu; kiểm soát glucose máu kém; có biến chứng khác ngoài thận có nồng độ hs-CRP cao hơn nhóm không có đặc điểm trên, $\mathrm{p}<0,05$.

\section{TÀI LIỆ THAM KHẢO}

1. Varma $V$, Varma $M$, Varma A, et al. (2016).Serum Total Sialic Acid and Highly Sensitive C-reactive Protein: Prognostic Markers for the Diabetic Nephropathy.J Lab Physicians. $8(1): 25-9$.

2. Shaheer AK, Tharayil JK, Krishna PW. (2017). A Comparative Study of High Sensitivity C-Reactive Protein and Metabolic Variables in Type 2 Diabetes Mellitus with and without Nephropathy.J Clin Diagn Res. 11(9):BC01-BC04.

3. Knight ML. (2015).The Application of HighSensitivity C-Reactive Protein in Clinical Practice: A 2015 Update. US Pharm; 40(2): 50-53.

4. Sinha SK, Nicholas SB, Sung JH, et al. (2019). hs-CRP Is Associated With Incident Diabetic Nephropathy: Findings From the Jackson Heart Study.Diabetes Care. 42(11):2083-2089.

5. Trân Minh Triết (2019).Khảo sát nồng độ Leptin huyết thanh và một số yếu tố nguy cơ tim mach ở bệnh nhân tiền đái tháo đường. Luận án Tiến sĩ. Trường đại học $Y$ Dược Huế.

6. Trân Thì Thu Hương, Nguyễn Viết Dũng, Dương Hông Thái và cộng sự (2013). Nghiến cứu mối liên quan giữa nồng độ hs-CRP với một số yếu tố nguy cơ tim mạch ở cán bộ diện bảo vế sức khoẻ tỉnh Thái nguyến. Tap chi Y Yọc thực hành 879 (3); 93-96.

7. Jeong ' $H$, Baek SY, Kim SW, et al. (2019).C reactive protein level as a marker for dyslipidaemia, diabetes and metabolic syndrome: results from the Korea National Health and Nutrition Examination Survey.BMJ Open. 9(8):e029861. 